\title{
Impact of dipeptidyl peptidase-4 inhibitors on serum adiponectin: a meta-analysis
}

\author{
Xin Liu', Peng Men², Yuhui Wang ${ }^{1}$, Suodi Zhai ${ }^{2}$ and George Liu ${ }^{1 *}$
}

\begin{abstract}
Background: Adiponectin, an adipose-specific protein, is negatively correlated with pro-atherogenic low-density lipoprotein cholesterol (LDL-C) and other cardiovascular risk factors such as insulin resistance. Therefore, low levels of adiponectin are associated with a higher risk for diabetes and cardiovascular disease. Dipeptidyl peptidase-4 inhibitors (DPP4i) have been used for the treatment of type 2 diabetes mellitus (T2DM) as reversible inhibitors through interacting with DPP4 substrate and increase serum incretins such as glucagon-like peptide-1 (GLP-1). The present study aimed to evaluate the effect of DPP4i on serum adiponectin in T2DM patients.

Methods: The PubMed, Embase, and Cochrane library databases were searched from inception to February 2016. Randomized controlled trials, evaluating the DPP4i (sitagliptin and vildagliptin) versus comparator (placebo or active-comparison), in T2DM patients with duration of $\geq 12$ weeks, were identified. Weighted differences in means of adiponectin levels were calculated by using a fixed or random-effects model.

Results: Ten randomized controlled trials, including 1,495 subjects, were identified. Compared with placebo, DPP4i (sitagliptin and vildagliptin) treatment significantly elevated adiponectin levels by $0.74 \mu \mathrm{g} / \mathrm{mL}$ (95\% confidence interval [Cl], 0.45 to 1.03) relative to that using an active-comparison by $0.00 \mu \mathrm{g} / \mathrm{mL}(95 \% \mathrm{Cl},-0.57$ to 0.56$)$. Compared with active-comparison, vildagliptin treatment increased adiponectin levels by $0.32 \mu \mathrm{g} / \mathrm{mL}(95 \% \mathrm{Cl},-0.01$ to 0.65$)$, whereas sitagliptin treatment decreased adiponectin levels by $-0.24 \mu \mathrm{g} / \mathrm{mL}(95 \% \mathrm{Cl},-1.07$ to 0.58$)$. Trials examining effects of other DPP4i were not found.
\end{abstract}

Conclusions: Sitagliptin and vildagliptin increased serum adiponectin levels and had no stronger effect than traditional oral antidiabetic drugs. Further trials with larger sample size are needed to confirm the results and investigate the association between serum adiponectin levels and treatment of other DPP-4 inhibitors.

Trial registration: Registration No in PROSPERO: CRD42016037399.

Keywords: Adiponectin, Dipeptidyl peptidase-4 inhibitors, Sitagliptin, Vildagliptin, Type 2 diabetes mellitus

\section{Background}

Obesity is strongly associated with type 2 diabetes mellitus (T2DM) and cardiovascular mortality [1]. Therefore, efforts have been made to better understand mechanisms underlying the etiology of obesity and cardiovascular disease. Adipocytes are not only energy-storing cells, but also secrete bioactive substances such as adiponectin $[2,3]$. Adiponectin is an adipose-specific collagen-like protein that adheres to injured arterial endothelial walls [1]. The adiponectin gene is located on chromosome $3 \mathrm{q} 27$ and has

\footnotetext{
* Correspondence: georgeliu@bjmu.edu.cn

${ }^{1}$ Institute of Cardiovascular Sciences, School of Basic Medical Science, Peking University Health Science Center, 38 Xueyuan Road, Beijing 100191, China

Full list of author information is available at the end of the article
}

been linked to metabolic syndrome and T2DM [4]. Adiponectin is often reduced along with insulin resistance progression in T2DM [5].

Previous studies have indicated that adiponectin possessed favorable anti-diabetic and anti-atherogenic activities [6,7]. Adiponectin levels are lower in patients with T2DM, which is a common co-morbidity of obesity [8]. Adiponectin is positively correlated with insulin sensitivity in humans and animals [9], and negatively correlated with myocardial infarctions [10]. Plasma adiponectin levels are markedly lower in patients with coronary artery disease compared with age- and BMI-matched controls [11]. Adiponectin also has a cardioprotective effect during 
ischemia-reperfusion injury [12]. Hypoadiponectinemia has been related to cardiac hypertrophy [13].

Increased adiponectin levels improve atherosclerosis in patients with T2DM or insulin resistance. Thiazolidinediones, which are useful glucose-lowering agents that have off-target or unwanted side effects, increase adiponectin levels in humans and mice [14, 15]. GLP-1, mainly in the form of incretin, increases adiponectin secretion in obese mice [16]. Dipeptidyl peptidase-4 inhibitors (DPP4i), or gliptins, lower glucose levels during fasting and postprandial states via preventing the inactivation of incretin hormones $[17,18]$. Clinical studies have indicated that gliptins improve pancreatic $\beta$-cell function in T2DM patients $[19,20]$. In animals, administration of DPP4i increases diet-induced decline in adiponectin levels [21]. Investigations on the effect of gliptin on plasma adiponectin in T2DM patients are limited, and the available data remains controversial [22-24]. In 2008, the U.S. Food and Drug Administration and the European Medicines Agency simultaneously required a demonstration of cardiovascular safety for all new glucose-lowering medications. Based on the reported benefits of higher adiponectin levels, adiponectin may be potentially used as a novel surrogate cardiovascular indicator and biomarker for antidiabetic agents. Therefore, to better understand gliptin activity on adiponectin, a meta-analysis of clinical trial data on DPP4i was conducted in adult T2DM patients.

\section{Methods}

\section{Search strategy}

In consultation with a medical librarian, we established a search strategy for the PubMed, Embase, and Cochrane Library using the following query terms: "sitagliptin," "vildagliptin," "teneligliptin," "saxagliptin," "linagliptin," "anagliptin," or "alogliptin". Randomized controlled trials published in English (from inception to February 2016) were included in the analysis. Two researchers independently searched for studies and any disagreement was resolved through discussion.

\section{Study selection}

Studies were included in the meta-analysis when they described a randomized clinical trial involving T2DM patients that lasted at least 12 weeks and compared a drug to a placebo or an active comparator other than a DPP4i. Exclusion criteria consisted of nonhuman studies, review articles, observational studies or case reports, non-glucose-lowering therapies, duplicate publications, short-term studies (therapies duration of $<12$ weeks) and studies in which changes in adiponectin levels was not reported or could not be calculated. The corresponding authors were contacted when clarification on specific aspects of the study was required. The inclusion and exclusion criteria were objectively evaluated by two reviewers.

\section{Data extraction and outcomes}

Two researchers (X.L. and P.M.) extracted data and used a standardized form of recording study information (author, publication year, sample size, trial duration and controls) and population characteristics (body mass index, age, sex, body weight, and baseline levels of glycosylated hemoglobin and adiponectin). Disagreement was resolved by discussion. The primary outcome was assessed using the difference between the final and baseline adiponectin levels. All included studies recorded mean adiponectin levels compared to that using placebo or active comparators.

\section{Quality appraisal}

Two researchers independently evaluated the quality of each clinical trial according to the Cochrane risk of bias tool [25]. This assessment included low, unclear and high risk for bias based on random sequence generation, allocation concealment, blinding of participants, blinding of outcome assessment, incomplete outcome data, selective reporting and other bias. Discrepancies were resolved by discussion or consultation of a third reviewer.

\section{Statistical analysis}

Statistical analysis were performed using Review Manager (Revman 5.1; Cochrane Collaboration) and STATA 12.0. Pooled weighted mean differences (WMD) and 95\% confidence intervals (CIs) were calculated using the Mantel-Haenszel (M-H) fixed effects model when there was no evidence of significant heterogeneity for outcomes or a random effects model when significant heterogeneity for outcomes was present. Heterogeneity among studies was assessed using a Chi-squared test and quantified using Higgins $\mathrm{I}^{2}$. To account for low statistical power of the Chi-squared test for heterogeneity, $p=0.10$ was considered insignificant. $\mathrm{I}^{2}$ ranging from 0 to $50 \%$ indicated that there was no important heterogeneity, and $\mathrm{I}^{2}$ values ranging from 50 to $100 \%$ suggested major heterogeneity, which was further explored using sensitivity analysis. Publication bias was examined by Egger's tests if there were at least five studies for each outcome.

\section{Results}

\section{Trial characteristics and quality}

Initially, 11,885 citations were found to meet the inclusion criteria. A study inclusion flowchart was presented in Fig. 1. After removal of inappropriate studies, ten randomized controlled trials including 1,495 subjects were identified, four studies were performed in Italy, one in Germany, and five in Japan. Characteristics of the 10 intervention studies are shown in Table 1. Trial quality was evaluated by using the Cochrane risk of bias tool 


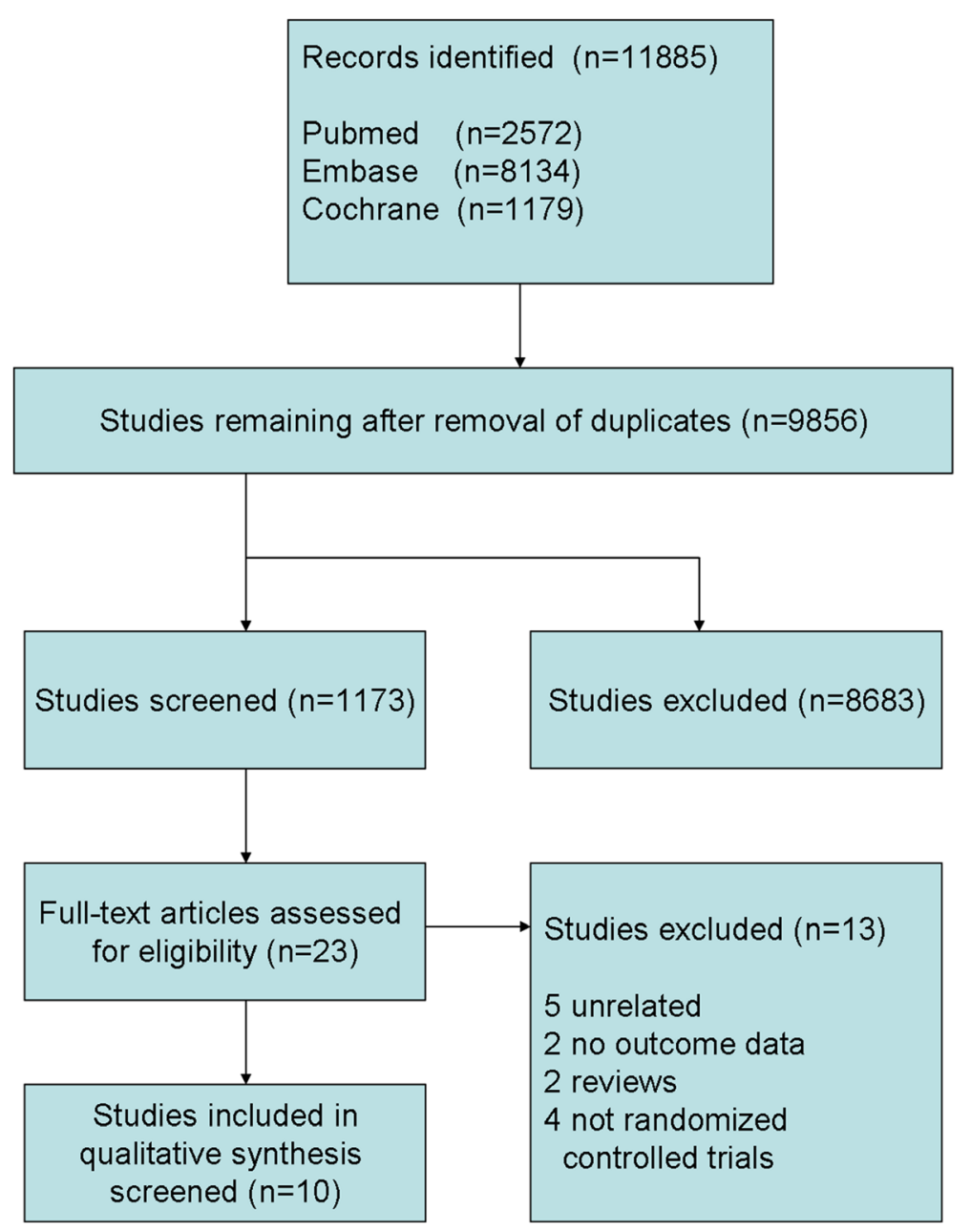

Fig. 1 Flow chart of studies included in the meta-analysis

(Fig. 2). Five studies fully fit the seven factors. Two studies were adequate for six of the seven factors, one study was adequate for five of the seven factors and two studies were adequate for four of the seven factors.

\section{Efficacy outcomes}

Results of the analysis of gliptin-adiponectin efficacy are presented in Figs. 3 and 4. Compared with placebo group, DPP4i (sitagliptin and vildagliptin) treatment significantly elevated adiponectin levels by $0.74 \mu \mathrm{g} / \mathrm{mL}$ (95\% confidence interval [CI], 0.45 to $1.03 ; p=0.74 ; \mathrm{I}^{2}=0 \%$; weighted mean baseline adiponectin: $5.10 \pm 0.90 \mu \mathrm{g} / \mathrm{mL} v s .5 .30 \pm 1.15 \mu \mathrm{g} /$ $\mathrm{mL})$ relative to that using an active comparator by $0.00 \mu \mathrm{g} /$ $\mathrm{mL}$ (95\% CI, -0.57 to $0.56 ; p<0.01 ; \mathrm{I}^{2}=84 \%$; weighted mean baseline adiponectin: $5.05 \pm 2.12 \mu \mathrm{g} / \mathrm{mL} v s .5 .10 \pm$ $2.01 \mu \mathrm{g} / \mathrm{mL})$. Compared to active comparator, vildagliptin increased adiponectin levels by $0.32 \mu \mathrm{g} / \mathrm{mL}$ (95\% CI, -0.01 to $0.65 ; p=0.91 ; \mathrm{I}^{2}=0 \%$; weighted mean baseline adiponectin: $4.40 \pm 2.18 \mu \mathrm{g} / \mathrm{mL} v s .4 .41 \pm 1.98 \mu \mathrm{g} / \mathrm{mL}$ ), whereas sitagliptin decreased levels by $-0.24 \mu \mathrm{g} / \mathrm{mL}$ (95\% CI, -1.07 to $0.58 ; p<0.01 ; \mathrm{I}^{2}=86 \%$; weighted mean baseline adiponectin: $5.71 \pm 2.06 \mu \mathrm{g} / \mathrm{mL} v s .5 .76 \pm 2.03 \mu \mathrm{g} / \mathrm{mL})$. Trials that examined the effect of other DPP4 inhibitors were not found.

\section{Heterogeneity and publication bias}

A significant heterogeneity was observed in the sitagliptinactive comparator group and a sensitivity analysis was then performed in Fig. 5, which indicated that Derosa's study had a significant effect on the result. Heterogeneity was not significant after particular study was excluded from the analysis $\left(p=0.48 ; \mathrm{I}^{2}=0 \%\right)$, and in turn showed that sitagliptin had no stronger effect on serum adiponectin levels compared to traditional oral antidiabetic drugs $(0.26 \mu \mathrm{g} / \mathrm{mL}, 95 \% \mathrm{CI},-0.12$ to 0.63 ; Fig. 6). According to Egger's test, no publication bias was observed among the five sitagliptin studies $(p=0.082)$. 
Table 1 Characteristics of the 10 studies included in the meta-analysis

\begin{tabular}{|c|c|c|c|c|c|c|c|c|c|c|}
\hline \multirow[t]{2}{*}{ Studies } & \multirow[t]{2}{*}{ Patients (N) } & \multirow[t]{2}{*}{ Treatment } & \multirow{2}{*}{$\begin{array}{l}\text { Diabetes duration } \\
\text { (months) }\end{array}$} & \multirow{2}{*}{$\begin{array}{l}\text { Adiponectin } \\
(\mu \mathrm{g} / \mathrm{mL})\end{array}$} & \multirow[t]{2}{*}{$\mathrm{HbA}_{1 \mathrm{c}}(\%)$} & \multirow{2}{*}{$\begin{array}{l}\text { Treatment duration } \\
\text { (months) }\end{array}$} & \multicolumn{4}{|c|}{ Patient characteristics } \\
\hline & & & & & & & BMI $\left(\mathrm{kg} / \mathrm{m}^{2}\right)$ & Age (years) & Male (N) & Weight (kg) \\
\hline \multirow[t]{2}{*}{ Derosa, 2012 [22] } & 91 & sitagliptin + metformin & 5.8 & 5.0 & 8.1 & 12 & 28.1 & 55.9 & 42 & 78.4 \\
\hline & 87 & placebo + metformin & 5.4 & 5.2 & 8.0 & & 28.9 & 54.8 & 44 & 78.6 \\
\hline \multirow[t]{2}{*}{ Derosa, 2010 [23] } & 75 & sitaliptin + pioglitazone & 60 & 5.4 & 8.5 & 12 & 27.9 & 57 & 37 & 78.7 \\
\hline & 76 & metformin + pioglitazone & 72 & 5.3 & 8.4 & & 27.7 & 58 & 39 & 77.3 \\
\hline \multirow[t]{2}{*}{ Forst, 2013 [45] } & 22 & vildagliptin + metformin & 100.8 & 5.0 & 7.41 & 6 & Not available & Not available & Not available & 99.3 \\
\hline & 22 & glimepiride + metformin & 73.2 & 5.6 & 7.28 & & Not available & Not available & Not available & 93.7 \\
\hline \multirow[t]{2}{*}{ Mikada, 2014 [47] } & 14 & sitagliptin & 91.2 & 6.5 & 7.45 & 6 & 28.8 & 59.2 & 11 & 76.8 \\
\hline & 14 & miglitol & 111.6 & 7.4 & 6.90 & & 29.5 & 58.7 & 11 & 81.4 \\
\hline \multirow[t]{2}{*}{ Hibuse, 2014 [48] } & 16 & sitagliptin & 57.6 & 6.7 & 7.5 & 3 & 24.9 & 63 & 9 & Not available \\
\hline & 10 & sulfonylurea and/or biguanide & 45.6 & 4.6 & 7.8 & & 28.1 & 56 & 6 & Not available \\
\hline \multirow[t]{2}{*}{ Takeshita, 2015 [49] } & 30 & sitagliptin & 86.4 & 4.5 & 6.7 & 4 & 24.5 & 61.0 & 18 & 62.5 \\
\hline & 30 & mitiglinide & 145.2 & 5.0 & 6.9 & & 24.2 & 65.8 & 19 & 63.2 \\
\hline \multirow[t]{2}{*}{ Derosa, 2012 [50] } & 84 & vildagliptin + metformin & 6.1 & 5.2 & 8.1 & 12 & 27.9 & 54.2 & 42 & 76.9 \\
\hline & 83 & placebo + metformin & 6.3 & 5.4 & 8.2 & & 27.8 & 52.4 & 43 & 78.5 \\
\hline \multirow[t]{2}{*}{ Derosa, 2014 [51] } & 86 & vildagliptin & 6.9 & 4.8 & 7.9 & 6 & 27.9 & 59.8 & 42 & 77.8 \\
\hline & 81 & glimepiride & 6.7 & 4.5 & 7.8 & & 27.7 & 56.8 & 36 & 77.2 \\
\hline \multirow[t]{2}{*}{ Takeshita, 2015 [52] } & 58 & vildagliptin & Not available & 3.6 & 8.1 & 3 & 24.5 & Not available & 36 & 63.2 \\
\hline & 54 & liraglutide & Not available & 3.8 & 8.0 & & 25.4 & Not available & 35 & 65.8 \\
\hline \multirow[t]{2}{*}{ Shimoda, 2014 [53] } & 25 & sitagliptin & Not available & 7.0 & 7.3 & 3 & 24.9 & 63.9 & 16 & Not available \\
\hline & 25 & glimepiride & Not available & 7.6 & 7.5 & & 25.3 & 62.4 & 15 & Not available \\
\hline
\end{tabular}




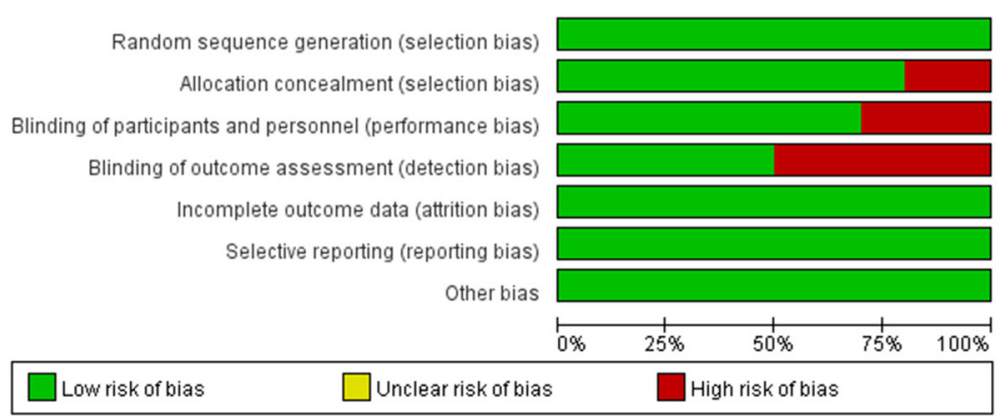

Fig. 2 Study quality as evaluated by Cochrane scores

\section{Discussion}

In current meta-analysis, the effect of DPP4i on adiponectin levels in T2DM patients was evaluated based on 10 clinical trials. A pooled efficacy estimate from those trials indicated that administration of sitagliptin and vildagliptin compared to placebo resulted in an increase in serum adiponectin levels, yet was not superior to that of active comparators.

T2DM is positively correlated with morbidity and mortality of diabetic vasculopathies and cardiovascular risks, including microangiopathies (e.g., renal failure and blindness) and macroangiopathies (atherosclerosis). Cardiovascular disease is a major cause of mortality in T2DM patients, and insulin or sulphonylureas effectively reduces the risk for microvascular complications, but not macrovascular events [26]. Of note, some studies have indicated that single and intensive glucose-lowering therapies might be less favorable to cardiovascular endpoints in T2DM $[27,28]$. Thus, antidiabetic therapy must be performed on the basis of future cardiovascular aspects.

Body fat distribution, especially visceral fat accumulation, is an early sign of obesity-related disorders such as cardiovascular disease and is associated with atherosclerosis via dysfunctional adipocytes and downregulated production of protective adipocytokines such as adiponectin. Obesity also decreases adiponectin sensitivity by downregulating the expression of AdipoR1 and AdipoR2 adiponectin receptors, which in turn leads to insulin resistance [29].

Adiponectin has an insulin-sensitizing effect by activating adenosine monophosphate activated protein kinase (AMPK) signaling through binding to AdipoR1 and AdipoR2. Then, AMPK stimulates cellular metabolism and enhances glucose uptake, fatty acid oxidation, and glucose utilization, thereby causing an increase in insulin sensitivity [30]. Adiponectin prevents atherosclerosis by inhibiting the expression of monocyte adhesion molecules and endothelial synthesis of pro-inflammatory chemokine by inactivating nuclear factor-kappaB $[31,32]$ as well as suppressing proliferation of vascular smooth muscle cells by targeting extracellular signal-regulated kinase [33].

Adiponectin regulates inflammatory responses in atherosclerotic lesions by interacting with IL-10 and upregulating the expression of tissue inhibitor of metalloproteinase-1 [34]. In apoE-deficient mice, adenovirally-mediated increases in adiponectin levels inhibit the progression of atherosclerotic lesions by downregulating VCAM-1 and SRA [35, 36]. Adiponectin diminishes infarct size, apoptosis and inflammatory cytokine in ischemia-reperfusion models through both AMPK- and COX-2-dependent mechanisms [12]. Adiponectin improves cardiac hypertrophy by inhibiting hypertrophic signaling in the myocardium through the

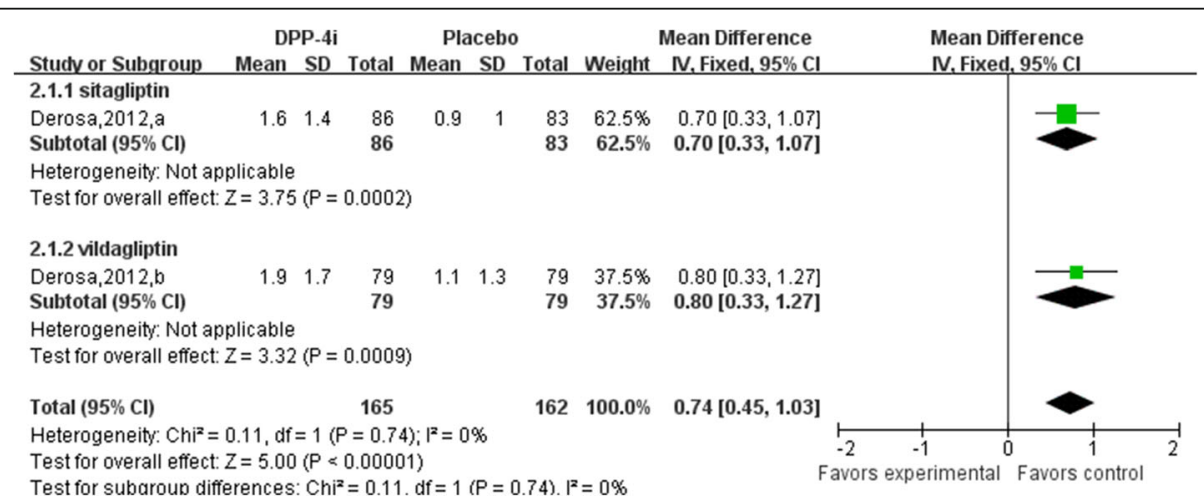

Fig. 3 Meta-analysis of the effect of DPP4i treatment versus placebo on serum adiponectin levels 


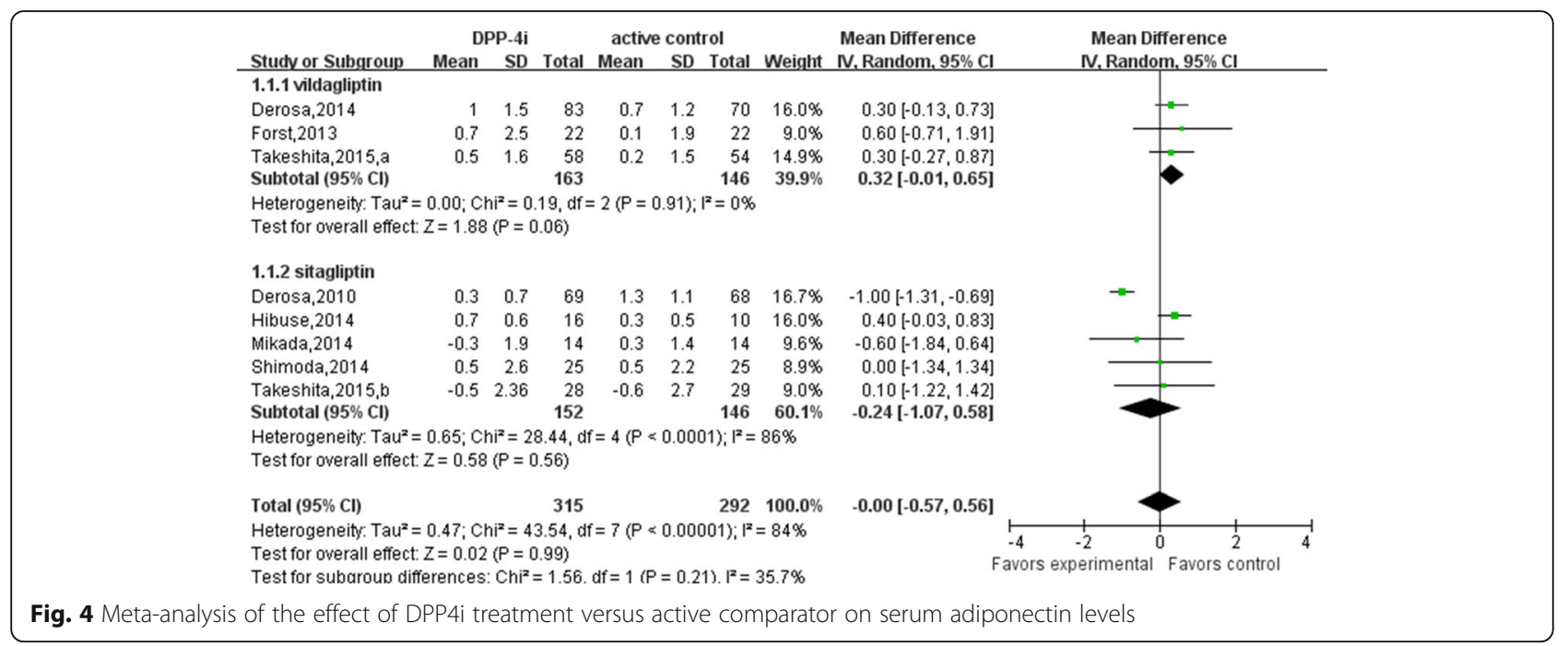

activation of AMPK and extracellular signal-regulated kinase (ERK).

PPAR- $\gamma$ agonists exhibit favorable effects on cardiovascular outcomes in T2DM patients [37, 38]. Thiazolidinediones, which are synthetic PPAR- $\gamma$ ligands, stimulate serum adiponectin by inducing the expression of the adiponectin gene via direct interaction with the PPAR- $\gamma$ / retinoid $\mathrm{X}$ receptor (RXR) via peroxisome-proliferator responsive elements (PPREs) present in the adiponectin promoter region [39]. Adiponectin-deficient mice do not show any improvements in atherosclerotic areas after PPAR- $\gamma$ activation [40].

Incretin-based therapies, GLP-1 agonists, and DPP4 inhibitors offer optimal glucose-lowering effect without increasing the risk for hypoglycemia and weight gain [41]. Exendin-4, which is a GLP-1R agonist, upregulates adiponectin mRNA and increases secretion of adiponectin via a protein kinase A pathway [42]. Inhibition of DPP4 leads to an increase in the GLP-1 expression, which in turn enhances insulin activity. Sitagliptin and vildagliptin resulted in an increase in adiponectin levels in the current study, although its underlying mechanism remained unclear. Due to a significant effect on heterogeneity, Derosa's study was excluded according to the sensitivity analysis. One possible reason for the effect might be the difference of population race between Derosa's study (among Italian) and another four studies (among Japanese). Patient baseline level of $\mathrm{HbA}_{1 \mathrm{c}}$ in Derosa's research exceeded $8.0 \%$ while other four studies were between 6.7 to $7.8 \%$, indicating that baseline levels of glycosylated hemoglobin might present an effect on adiponectin in response to DPP4i treatment. Treatment duration might be the third cause of heterogeneity effect between Derosa's study (12 months) and another four studies (3-6 months).

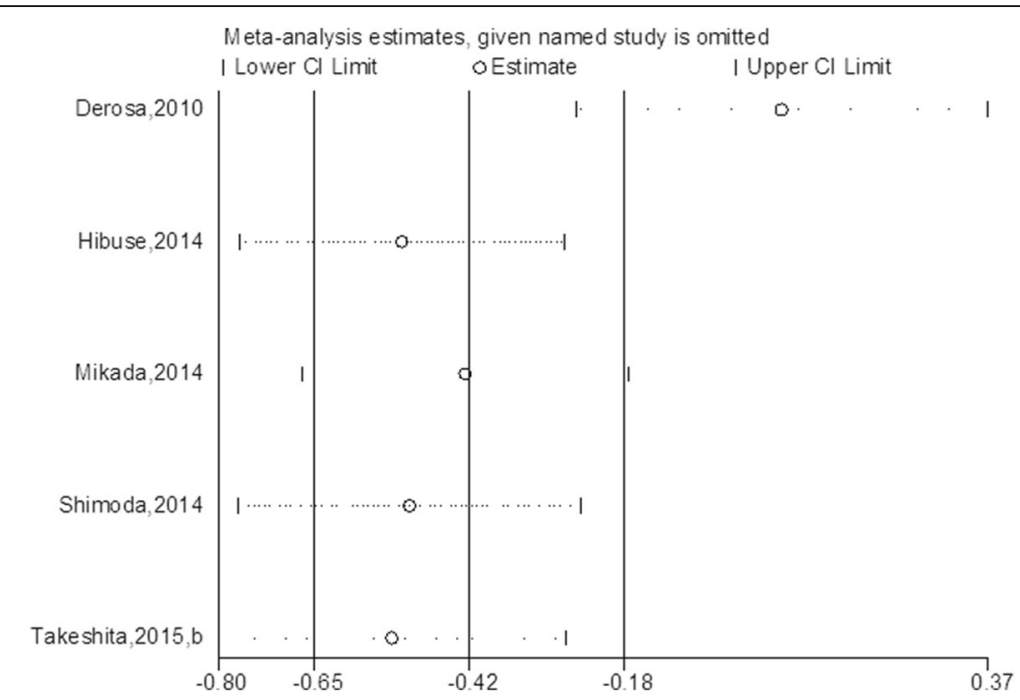

Fig. 5 Sensitivity analysis of the studies reporting the effect of sitagliptin comparing with active control on serum adiponectin levels 


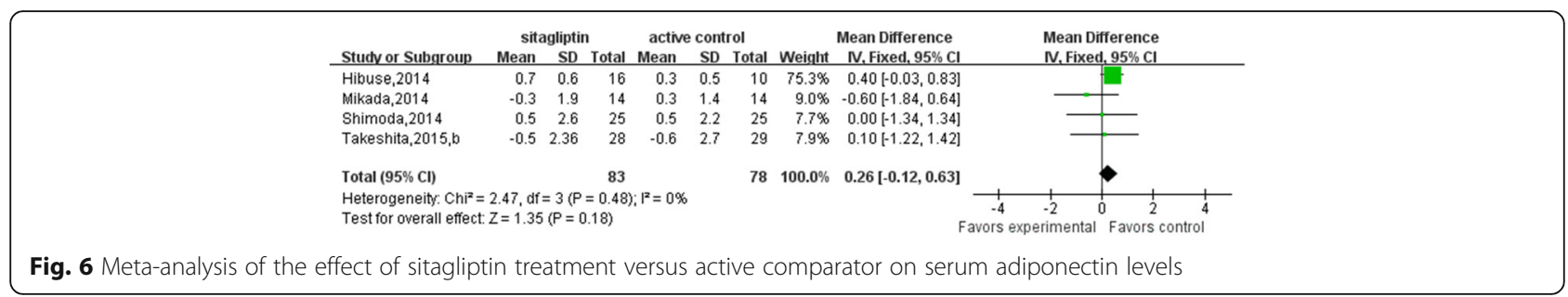

Sitagliptin or vildagliptin promotes secretion of adiponectin by enhancing the production of active GLP-1 [43]. Weight reduction or reduced BMI, waist circumference, and visceral fat accumulation may also elevate serum adiponectin levels $[8,44]$. Sitagliptin induces a significant increase in adiponectin levels prior to weight loss, thereby suggesting that a reduction in visceral fat mass from long-term treatment causes changes in adiponectin levels [22]. Vildagliptin treatment elevates plasma adiponectin levels and this may have been due to a reduction in fat mass [45]. Speculations might be obtained that sitagliptin has no better specific selectivity on targeting proteins in the adiponectin-secretion pathway than active comparators. Oxidative stress can also cause dysregulation of secretion of fat-derived hormones such as adiponectin [46]. Sitagliptin or vildagliptin increases the expression of antioxidative enzymes, as well as promotes adiponectin secretion directly or indirectly by targeting signals of oxidative stress. The role of gliptins in oxidative stress must be investigated to better understand the mechanism underlying adiponectin secretion.

\section{Limitations}

Our study has several limitations such as the inclusion of a small sample size as well as English-only clinical trials. Furthermore, unpublished results were not included, which in turn might cause potential publication bias. Also, changes in appetite or food intake were not recorded and the clinical trials were conducted for a short duration. Some heterogeneity was also observed in some of the results, although measures were taken to overcome them by performing a sensitivity analysis. Parallel evaluation of related adipokines was also not performed.

\section{Conclusions}

DPP4 inhibitors promote the secretion of serum adiponectin in T2DM patients, thereby indicating that these have a cardioprotective effect. Further trials with larger sample size are needed to confirm the results and investigate the association between serum adiponectin levels and treatment of other DPP4 inhibitors. Long-term efficacy and cardiovascular endpoints should be studied to better guide patient treatment with or without other glucose-lowering agents.

\section{Acknowledgments}

We would like to thank Dr. Xunde Xian of the Department of Molecular Genetics, UT Southwestern Medical Center in Dallas, TX for his advice and suggestions relating to this manuscript.

This work was performed at the Peking University Health Science Center, 38 Xueyuan Road, Beijing 100191, China.

The authors declare that they have no potential conflicts of interest with respect to this study. Grants from the National Natural Science Foundation of the People's Republic of China awarded to G. Liu (No. 81470555) and Y. Wang (No. 81570787) supported this study.

\section{Funding}

This work is supported in part by the National Natural Science Foundation of the People's Republic of China awarded to G. Liu (No. 81470555) and Y. Wang (No. 81570787).

\section{Availability of data and material}

Please contact author for data requests.

\section{Authors' contributions}

GL designed the study and revised the manuscript, $X L$ and PM extracted the data, PM, YW and SZ evaluated the RCTs quality, SZ and GL verified the data. $\mathrm{XL}$ and $\mathrm{PM}$ researched the data and wrote the manuscript. GL contributed to interpreting the results, draft reviewing, and finalizing the manuscript. All authors read and approved the final manuscript.

\section{Competing interests}

The authors declare that they have no competing interests.

Consent for publication

Not applicable.

Ethics approval and consent to participate

Not applicable.

\section{Author details}

${ }^{1}$ Institute of Cardiovascular Sciences, School of Basic Medical Science, Peking University Health Science Center, 38 Xueyuan Road, Beijing 100191, China.

${ }^{2}$ Department of Pharmacy, Peking University Third Hospital, Beijing, China.

Received: 20 May 2016 Accepted: 10 November 2016

Published online: 23 November 2016

\section{References}

1. Arita Y, Kihara S, Ouchi N, Takahashi M, Maeda K, Miyagawa J, Hotta K, Shimomura I, Nakamura T, Miyaoka K, et al. Paradoxical decrease of an adipose-specific protein, adiponectin, in obesity. Biochem Biophys Res Commun. 1999;257:79-83.

2. Berg $\mathrm{AH}$, Scherer PE. Adipose tissue, inflammation, and cardiovascular disease. Circ Res. 2005;96:939-49.

3. Yang Q, Graham TE, Mody N, Preitner F, Peroni OD, Zabolotny JM, Kotani K, Quadro L, Kahn BB. Serum retinol binding protein 4 contributes to insulin resistance in obesity and type 2 diabetes. Nature. 2005;436:356-62.

4. Mori Y, Otabe S, Dina C, Yasuda K, Populaire C, Lecoeur C, Vatin V, Durand E, Hara K, Okada T, et al. Genome-wide search for type 2 diabetes in Japanese affected sib-pairs confirms susceptibility genes on 3q, 15q, and 20q and identifies two new candidate Loci on 7p and 11p. Diabetes. 2002;51:1247-55.

5. Hotta K, Funahashi T, Bodkin NL, Ortmeyer HK, Arita Y, Hansen BC, Matsuzawa Y. Circulating concentrations of the adipocyte protein 
adiponectin are decreased in parallel with reduced insulin sensitivity during the progression to type 2 diabetes in rhesus monkeys. Diabetes. 2001;50:1126-33.

6. Kishida K, Funahashi T, Shimomura I. Molecular mechanisms of diabetes and atherosclerosis: role of adiponectin. Endocr Metab Immune Disord Drug Targets. 2012;12:118-31.

7. Kishida K, Funahashi T, Shimomura I. Adiponectin as a routine clinical biomarker. Best Pract Res Clin Endocrinol Metab. 2014;28:119-30.

8. Hotta K, Funahashi T, Arita Y, Takahashi M, Matsuda M, Okamoto Y, Iwahashi H, Kuriyama H, Ouchi N, Maeda K, et al. Plasma concentrations of a novel, adipose-specific protein, adiponectin, in type 2 diabetic patients. Arterioscler Thromb Vasc Biol. 2000;20:1595-9.

9. Guo X, Saad MF, Langefeld CD, Williams AH, Cui J, Taylor KD, Norris JM, Jinagouda S, Darwin CH, Mitchell BD, et al. Genome-wide linkage of plasma adiponectin reveals a major locus on chromosome $3 q$ distinct from the adiponectin structural gene: the IRAS family study. Diabetes. 2006;55:1723-30.

10. Pischon T, Girman CJ, Hotamisligil GS, Rifai N, Hu FB, Rimm EB. Plasma adiponectin levels and risk of myocardial infarction in men. JAMA. 2004;291:1730-7.

11. Ouchi N, Kihara S, Arita Y, Maeda K, Kuriyama H, Okamoto Y, Hotta K, Nishida M, Takahashi M, Nakamura T, et al. Novel modulator for endothelial adhesion molecules: adipocyte-derived plasma protein adiponectin. Circulation. 1999;100:2473-6.

12. Shibata R, Sato K, Pimentel DR, Takemura Y, Kihara S, Ohashi K, Funahashi T, Ouchi N, Walsh K. Adiponectin protects against myocardial ischemiareperfusion injury through AMPK- and COX-2-dependent mechanisms. Nat Med. 2005;11:1096-103.

13. Shibata R, Ouchi N, Ito M, Kihara S, Shiojima I, Pimentel DR, Kumada M, Sato K, Schiekofer S, Ohashi K, et al. Adiponectin-mediated modulation of hypertrophic signals in the heart. Nat Med. 2004;10:1384-9.

14. Combs TP, Wagner JA, Berger J, Doebber T, Wang WJ, Zhang BB, Tanen M, Berg AH, O'Rahilly S, Savage DB, et al. Induction of adipocyte complement-related protein of 30 kilodaltons by PPARgamma agonists: a potential mechanism of insulin sensitization. Endocrinology. 2002:143:998-1007.

15. Maeda N, Takahashi M, Funahashi T, Kihara S, Nishizawa H, Kishida K, Nagaretani H, Matsuda M, Komuro R, Ouchi N, et al. PPARgamma ligands increase expression and plasma concentrations of adiponectin, an adiposederived protein. Diabetes. 2001;50:2094-9.

16. Pocai A, Carrington PE, Adams JR, Wright M, Eiermann G, Zhu L, Du X, Petrov A, Lassman ME, Jiang G, et al. Glucagon-like peptide 1/glucagon receptor dual agonism reverses obesity in mice. Diabetes. 2009;58:2258-66.

17. Nauck MA, Meininger G, Sheng D, Terranella L, Stein PP. Efficacy and safety of the dipeptidyl peptidase-4 inhibitor, sitagliptin, compared with the sulfonylurea, glipizide, in patients with type 2 diabetes inadequately controlled on metformin alone: a randomized, double-blind, non-inferiority trial. Diabetes Obes Metab. 2007;9:194-205.

18. Brazg R, Xu L, Dalla Man C, Cobelli C, Thomas K, Stein PP. Effect of adding sitagliptin, a dipeptidyl peptidase-4 inhibitor, to metformin on 24-h glycaemic control and beta-cell function in patients with type 2 diabetes. Diabetes Obes Metab. 2007;9:186-93.

19. Xu L, Man CD, Charbonnel B, Meninger G, Davies MJ, Williams-Herman D, Cobelli C, Stein PP. Effect of sitagliptin, a dipeptidyl peptidase-4 inhibitor, on beta-cell function in patients with type 2 diabetes: a model-based approach. Diabetes Obes Metab. 2008;10:1212-20.

20. Derosa G, Maffioli P. Dipeptidyl peptidase-4 inhibitors: 3 years of experience. Diabetes Technol Ther. 2012;14:350-64.

21. Shah Z, Kampfrath T, Deiuliis JA, Zhong J, Pineda C, Ying Z, Xu X, Lu B, Moffatt-Bruce $S$, Durairaj $R$, et al. Long-term dipeptidyl-peptidase 4 inhibition reduces atherosclerosis and inflammation via effects on monocyte recruitment and chemotaxis. Circulation. 2011;124:2338-49.

22. Derosa G, Carbone A, Franzetti I, Querci F, Fogari E, Bianchi L, Bonaventura A, Romano D, Cicero AF, Maffioli P. Effects of a combination of sitagliptin plus metformin vs metformin monotherapy on glycemic control, beta-cell function and insulin resistance in type 2 diabetic patients. Diabetes Res Clin Pract. 2012;98:51-60.

23. Derosa G, Maffioli P, Salvadeo SA, Ferrari I, Ragonesi PD, Querci F, Franzetti IG, Gadaleta G, Ciccarelli L, Piccinni MN, et al. Effects of sitagliptin or metformin added to pioglitazone monotherapy in poorly controlled type 2 diabetes mellitus patients. Metabolism. 2010;59:887-95.
24. Kubota Y, Miyamoto M, Takagi G, Ikeda T, Kirinoki-Ichikawa S, Tanaka K, Mizuno K. The dipeptidyl peptidase-4 inhibitor sitagliptin improves vascular endothelial function in type 2 diabetes. J Korean Med Sci. 2012;27:1364-70.

25. Higgins JP, Altman DG, Gotzsche PC, Juni P, Moher D, Oxman AD, Savovic J, Schulz KF, Weeks L, Sterne JA. The Cochrane Collaboration's tool for assessing risk of bias in randomised trials. BMJ. 2011;343:d5928.

26. Intensive blood-glucose control with sulphonylureas or insulin compared with conventional treatment and risk of complications in patients with type 2 diabetes (UKPDS 33). UK Prospective Diabetes Study (UKPDS) Group. Lancet. 1998;352:837-53.

27. Gerstein HC, Miller ME, Byington RP, Goff Jr DC, Bigger JT, Buse JB, Cushman WC, Genuth S, Ismail-Beigi F, Grimm Jr RH, et al. Effects of intensive glucose lowering in type 2 diabetes. N Engl J Med. 2008;358:2545-59.

28. Duckworth W, Abraira C, Moritz T, Reda D, Emanuele N, Reaven PD, Zieve FJ, Marks J, Davis SN, Hayward R, et al. Glucose control and vascular complications in veterans with type 2 diabetes. N Engl J Med. 2009;360:129-39.

29. Tsuchida A, Yamauchi T, Ito Y, Hada Y, Maki T, Takekawa S, Kamon J, Kobayashi M, Suzuki R, Hara K, et al. Insulin/Foxo1 pathway regulates expression levels of adiponectin receptors and adiponectin sensitivity. J Biol Chem. 2004;279:30817-22.

30. Hopkins TA, Ouchi N, Shibata R, Walsh K. Adiponectin actions in the cardiovascular system. Cardiovasc Res. 2007;74:11-8.

31. Ouchi N, Kihara S, Arita Y, Okamoto Y, Maeda K, Kuriyama H, Hotta K, Nishida M, Takahashi M, Muraguchi M, et al. Adiponectin, an adipocytederived plasma protein, inhibits endothelial NF-kappaB signaling through a CAMP-dependent pathway. Circulation. 2000;102:1296-301.

32. Kobashi C, Urakaze M, Kishida M, Kibayashi E, Kobayashi H, Kihara S, Funahashi T, Takata M, Temaru R, Sato A, et al. Adiponectin inhibits endothelial synthesis of interleukin-8. Circ Res. 2005;97:1245-52.

33. Arita $Y$, Kihara S, Ouchi N, Maeda K, Kuriyama H, Okamoto Y, Kumada M, Hotta K, Nishida M, Takahashi M, et al. Adipocyte-derived plasma protein adiponectin acts as a platelet-derived growth factor-BB-binding protein and regulates growth factor-induced common postreceptor signal in vascular smooth muscle cell. Circulation. 2002;105:2893-8.

34. Kumada M, Kihara S, Ouchi N, Kobayashi H, Okamoto Y, Ohashi K, Maeda K, Nagaretani H, Kishida K, Maeda N, et al. Adiponectin specifically increased tissue inhibitor of metalloproteinase-1 through interleukin-10 expression in human macrophages. Circulation. 2004;109:2046-9.

35. Okamoto Y, Kihara S, Ouchi N, Nishida M, Arita Y, Kumada M, Ohashi K, Sakai N, Shimomura I, Kobayashi H, et al. Adiponectin reduces atherosclerosis in apolipoprotein E-deficient mice. Circulation. 2002;106:2767-70.

36. Yamauchi T, Kamon J, Waki H, Imai Y, Shimozawa N, Hioki K, Uchida S, Ito Y, Takakuwa K, Matsui J, et al. Globular adiponectin protected ob/ob mice from diabetes and ApoE-deficient mice from atherosclerosis. J Biol Chem. 2003:278:2461-8.

37. Charbonnel B, Dormandy J, Erdmann E, Massi-Benedetti M, Skene A. The prospective pioglitazone clinical trial in macrovascular events (PROactive): can pioglitazone reduce cardiovascular events in diabetes? Study design and baseline characteristics of 5238 patients. Diabetes Care. 2004;27:1647-53.

38. Dormandy JA, Charbonnel B, Eckland DJ, Erdmann E, Massi-Benedetti M, Moules IK, Skene AM, Tan MH, Lefebvre PJ, Murray GD, et al. Secondary prevention of macrovascular events in patients with type 2 diabetes in the PROactive Study (PROspective pioglitAzone Clinical Trial In macroVascular Events): a randomised controlled trial. Lancet. 2005;366:1279-89.

39. Iwaki M, Matsuda M, Maeda N, Funahashi T, Matsuzawa Y, Makishima M, Shimomura I. Induction of adiponectin, a fat-derived antidiabetic and antiatherogenic factor, by nuclear receptors. Diabetes. 2003;52:1655-63.

40. Hiuge-Shimizu A, Maeda N, Hirata A, Nakatsuji H, Nakamura K, Okuno A, Kihara S, Funahashi T, Shimomura I. Dynamic changes of adiponectin and S100A8 levels by the selective peroxisome proliferator-activated receptor-gamma agonist rivoglitazone. Arterioscler Thromb Vasc Biol. 2011:31:792-9

41. Davidson JA. Incretin-based therapies: focus on effects beyond glycemic control alone. Diabetes Ther. 2013;4:221-38.

42. Kim Chung le T, Hosaka T, Yoshida M, Harada N, Sakaue H, Sakai T, Nakaya Y. Exendin-4, a GLP-1 receptor agonist, directly induces adiponectin expression through protein kinase A pathway and prevents inflammatory adipokine expression. Biochem Biophys Res Commun. 2009;390:613-8.

43. Omoto S, Taniura T, Nishizawa T, Tamaki T, Shouzu A, Nomura S. Antiatherosclerotic effects of sitagliptin in patients with type 2 diabetes mellitus. Diabetes Metab Syndr Obes. 2015;8:339-45. 
44. Okauchi Y, Kishida K, Funahashi T, Noguchi M, Ogawa T, Ryo M, Okita K, Iwahashi H, Imagawa A, Nakamura T, et al. Changes in serum adiponectin concentrations correlate with changes in BMI, waist circumference, and estimated visceral fat area in middle-aged general population. Diabetes Care. 2009;32:e122

45. Forst T, Dworak M, Berndt-Zipfel C, Loffler A, Klamp I, Mitry M, Pfutzner A. Effect of vildagliptin compared to glimepiride on postprandial proinsulin processing in the beta cell of patients with type 2 diabetes mellitus. Diabetes Obes Metab. 2013;15:576-9.

46. Furukawa S, Fujita T, Shimabukuro M, Iwaki M, Yamada Y, Nakajima Y, Nakayama O, Makishima M, Matsuda M, Shimomura I. Increased oxidative stress in obesity and its impact on metabolic syndrome. J Clin Invest. 2004;114:1752-61.

47. Mikada A, Narita T, Yokoyama H, Yamashita R, Horikawa Y, Tsukiyama K, Yamada Y. Effects of miglitol, sitagliptin, and initial combination therapy with both on plasma incretin responses to a mixed meal and visceral fat in over-weight Japanese patients with type 2 diabetes. "The MASTER randomized, controlled trial". Diabetes Res Clin Pract. 2014;106:538-47.

48. Hibuse T, Maeda N, Kishida K, Kimura T, Minami T, Takeshita E, Hirata A, Nakagawa Y, Kashine S, Oka A, et al. A pilot three-month sitagliptin treatment increases serum adiponectin level in Japanese patients with type 2 diabetes mellitus-a randomized controlled trial START-J study. Cardiovasc Diabetol. 2014;13:96.

49. Takeshita Y, Takamura T, Kita Y, Takazakura A, Kato K, Isobe Y, Kaneko S. Sitagliptin versus mitiglinide switched from mealtime dosing of a rapidacting insulin analog in patients with type 2 diabetes: a randomized, parallel-group study. BMJ Open Diabetes Res Care. 2015;3:e000122.

50. Derosa G, Ragonesi PD, Carbone A, Fogari E, Bianchi L, Bonaventura A, Romano D, Cicero AF, Maffioli P. Vildagliptin added to metformin on beta-cell function after a euglycemic hyperinsulinemic and hyperglycemic clamp in type 2 diabetes patients. Diabetes Technol Ther. 2012;14:475-84.

51. Derosa G, Bonaventura A, Bianchi L, Romano D, Fogari E, D'Angelo A, Maffioli P. Comparison of vildagliptin and glimepiride: effects on glycaemic control, fat tolerance and inflammatory markers in people with type 2 diabetes. Diabet Med. 2014;31:1515-23.

52. Takeshita Y, Takamura T, Kita Y, Otoda T, Kato K, Wakakuri H, Yamada M, Misu H, Matsushima Y, Kaneko S. Vildagliptin vs liraglutide as a second-line therapy switched from sitagliptin-based regimens in patients with type 2 diabetes: A randomized, parallel-group study. J Diabetes Investig. 2015;6:192-200.

53. Shimoda S, Iwashita S, Sekigami T, Furukawa N, Matsuo Y, Ichimori S, Goto R, Maeda T, Watanabe E, Kondo T, et al. Comparison of the efficacy of sitagliptin and glimepiride dose-up in Japanese patients with type 2 diabetes poorly controlled by sitagliptin and glimepiride in combination. J Diabetes Investig. 2014:5:320-6.

\section{Submit your next manuscript to BioMed Central and we will help you at every step:}

- We accept pre-submission inquiries

- Our selector tool helps you to find the most relevant journal

- We provide round the clock customer support

- Convenient online submission

- Thorough peer review

- Inclusion in PubMed and all major indexing services

- Maximum visibility for your research

Submit your manuscript at www.biomedcentral.com/submit 